\title{
Phenotypic diversity in buffalo cows of the Jafarabadi, Murrah, and Mediterranean breeds
}

\author{
Marcos Paulo Gonçalves de Rezende(1), Paulo Costa Ferraz ${ }^{(1)}$, \\ Paulo Luiz Souza Carneiro ${ }^{(2)}$ and Carlos Henrique Mendes Malhado ${ }^{(2)}$
}

(1)Universidade Estadual do Sudoeste da Bahia (Uesb), Campus de Itapetinga, Praça Primavera, no 40, Primavera, CEP 45700 -000 Itapetinga, BA, Brazil.E-mail:mpgrezende@gmail.com, pcferraz2@hotmail.com ${ }^{(2)}$ Uesb, Departamento de Ciências Biológicas, Campus de Jequié, Rua José Moreira Sobrinho, s/no, Jequiezinho, CEP 45206-190 Jequié, BA, Brazil. E-mail: plscarneiro@gmail.com, carlosmalhado@gmail.com

\begin{abstract}
The objective of this work was to estimate the phenotypic diversity in Jafarabadi, Murrah, and Mediterranean buffalo cows (Bubalus bubalis). Thoracic perimeter, withers-and-rump height, body length, and biiliac, external biischiatic, external ilioischiatic, sacropubic, and mean biiliac diameters were measured. The following indexes were calculated: anamorphosis index, pelvic index, withers-to-rump ratio, body index, lateral-body index, relative body index, body capacity indexes 1 and 2, transversal pelvic index, longitudinal pelvic index, and thoracic-perimeter-to-withers ratio index. The effect of breed was evaluated using univariate (mean tests) and multivariate (size-free discriminant analysis and Fisher's linear discriminant function) analyses. The diversity among the breeds and their correlation with the variables were also evaluated using biplot graphs developed from principal component analysis. The breeds evaluated show a rectilinear, midline body model with similar capacity of muscular tissue development in body parts from which the most valuable cuts are extracted, and intermediate suitability for meat and milk production. The Jafarabadi breed has a larger body size, with a rear portion wider than longer, while the Murrah and Mediterranean breeds show similar biotypes, mainly differentiated in the pelvic region.
\end{abstract}

Index terms: Bubalus bubalis, biometric measurements, pelvimetry, zootechnical indexes.

\section{Diversidade fenotípica em búfalas Jafarabadi, Murrah e Mediterrâneo}

Resumo - O objetivo deste trabalho foi estimar a diversidade fenotípica em búfalas (Bubalus bubalis) das raças Jafarabadi, Murrah e Mediterrâneo. Mensuraram-se perímetro torácico, altura de anterior e de garupa, comprimento do corpo e diâmetros do biilíaco, biisquiático externo, ilioisquiático externo, sacropúbico e biilíaco médio. Calcularam-se os seguintes índices: de anamorfose, pélvico, relação cernelha-garupa, corporal, corporal-lateral, corporal relativo, capacidade corporal 1 e 2 , pélvico transversal, pélvico longitudinal e relação perímetro torácico-cernelha. Avaliou-se o efeito de raça por meio das análises univariada (teste de médias) e multivariada (análise discriminante independente do tamanho e função discriminante linear de Fisher). Também avaliaram-se a diversidade entre as raças e a sua relação com as variáveis, por meio de gráficos biplot, elaborados a partir da análise de componentes principais. As raças apresentam modelo corpóreo retilíneo, mediolíneo e com capacidade igual para desenvolvimento de tecido muscular em locais de onde são extraídos cortes nobres, com aptidões intermediárias para produção de carne e leite. A raça Jafarabadi apresenta maior porte corporal, assim como uma porção traseira mais larga do que comprida, enquanto a Murrah e a Mediterrâneo apresentam biótipos próximos, diferenciados principalmente na região pélvica.

Termos para indexação: Bubalus bubalis, medidas biométricas, pelvimetria, índices zootécnicos.

\section{Introduction}

Buffaloes (Bubalus bubalis) have great capacity of adaptation and resistance to various microclimates and production systems (Malhado et al., 2008) and are suitable for work and meat and milk production (Malhado et al., 2009), which adds interest to using them as an alternative livestock species in Brazil (Malhado et al., 2007). Murrah, Jafarabadi, and Mediterranean are among the water buffalo breeds officially recognized by the Brazilian Association of Buffalo Breeders (Albuquerque et al., 2006).

Phenotypic diversity evaluations on water buffalo breeds can help breeders to identify the suitability 
of each breed (Rezende et al., 2014b, 2016) and their qualities and problems as well as to design mating strategies so as to improve certain progeny characteristics (Mello \& Schimidt, 2008; Souza et al., 2015).

Measuring various anatomical parts of the animals can contribute to the phenotypic evaluation. For instance, the evaluation of the pelvic area of buffalo cows can contribute to identify animals with not as many delivery problems. Another tool for phenotypic evaluation can be the combined use of body measurements to develop zootechnical indexes, which has been reported as an efficient strategy to investigate the suitability of domestic animals (Cerqueira et al., 2011; Contreras et al., 2011; Meneses et al., 2013; Rezende et al., 2014a, 2016).

Multivariate statistics is an efficient alternative for data analysis, considering the large number of variables to be measured in production animals. The size-free discriminant analysis (SFDA), described by Reis et al. (1990) and Peres-Neto (1995), can be used to remove the effect of size on shape. The residual effect is increased when body measurements are taken in animals of different age, sex, or type of management they are subjected to, for example. SFDA improves the accuracy of results, which allows to better assess differences between treatments. Fisher's linear discriminant function (FDF) can also be used to reduce the p-dimensional space to a one-dimensional one, thus making the use of univariate statistics possible (Carneiro et al., 2007).

Moreover, principal component analysis enables rewriting the coordinates of the samples in an axis system more convenient to data analysis. According to Moita Neto \& Moita (1998), this technique allows evaluating the importance of the original variables from the statistical point of view, i.e., those given a higher weight in the linear combination of the first principal components are considered the most important.

The objective of this work was to estimate the phenotypic diversity in Jafarabadi, Murrah, and Mediterranean buffalo cows.

\section{Materials and Methods}

Data were collected in a farm located in the municipality of Maiquinique, in the southwest of the

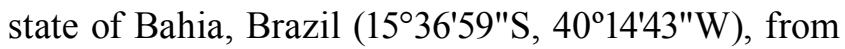

412 primiparous and multiparous buffalo cows of the Jafarabadi (78), Murrah (221), and Mediterranean (113) breeds aged $11.0 \pm 4.7,6.9 \pm 3.4$, and $8.4 \pm 4.1$ years, respectively.

The animals were subjected to a rotational grazing system in paddocks of average support capacity of 1 animal unit (equivalent to $450 \mathrm{~kg}$ ) per hectare using Urochloa decumbens (Stapf) R.D.Webster and $U$. humidicola (Rendle) Morrone \& Zuloaga grasses throughout the experimental period. The animals were provided with a mineral mixture in specific trough and water ad libitum. The prophylactic program of the farm followed a systematic schedule of vaccinations against foot-and-mouth disease, brucellosis, symptomatic carbuncle and rabies, and control of endo and ectoparasites, according to the needs of the herd.

The animals were kept in a cattle crush so that information regarding their identification could be collected and general body measurements (Bianchini et al., 2006; Mello \& Schimidt, 2008), as well as external and internal pelvic measurements (Araújo et al., 2014), could be performed. These measurements were combined to calculate the following indexes for conformity, production suitability (milk and meat), and ethnology (Marchiani Dubuc, 1991; Contreras et al., 2011; Rezende et al., 2014a): anamorphic index (thoracic perimeter squared divided by withers height, multiplied by 100); pelvic index (rump width divided by rump length, multiplied by 100); withers-to-rump ratio (withers height divided by rump height); body index (body length divided by thoracic perimeter); lateral-body index (withers height divided by body length, multiplied by 100); relative body index (body length multiplied by 100 , divided by withers height); body capacity index 1 (quotient between weight and body length); body capacity index 2 (quotient between weight and thoracic perimeter); transversal pelvic index (rump width divided by wither height, multiplied by 100); longitudinal pelvic index (rump length divided by withers height, multiplied by 100); and thoracicperimeter-to-withers ratio (thoracic perimeter divided by withers height).

The differences between breeds were evaluated using the analysis of variance (Anova), followed by Tukey's test, at 5\% probability, using the GLM procedure of SAS software (SAS Institute, Inc., Cary, NC, USA). The SFDA was used to remove the effect of size on shape (Peres-Neto, 1995). Regression residuals of each 
variable as affected by the first principal component were used in the multivariate analysis. The FDF was based on the first canonical variable of the SFDA procedure using SAS software (SAS Institute, Inc., Cary, NC, USA). Subsequently, Anova was performed on the first canonical variable, followed by Tukey's test, at $5 \%$ probability, to evaluate the breed equality hypothesis using the GLM procedure of SAS software (SAS Institute, Inc., Cary, NC, USA). Using Genes software (Universidade Federal de Viçosa, MG, Brazil), the method of Singh (1981), based on the average Euclidean distance, was used to reduce the number of variables, thus eliminating those that did not contribute much to breed differentiation considering three groups of characteristics (linear measures, pelvic measures and zootechnical indexes). Subsequently, the similarity degree between breeds was evaluated using principal component analysis, in scatter biplot graphs developed in Past software (Hammer et al., 2001). The dissimilarity matrices between breeds were calculated using the generalized Mahalanobis distance $\mathrm{D}^{2}$ in the Genes program.

\section{Results and Discussion}

Buffalo cows of the three breeds evaluated had mean weights and body heights within the standards for buffalo cows (Andrade \& Garcia, 2005) (Table 1). The higher body (withers and rump measures) of the Jafarabadi buffalo cows may be related to their biotype, which is characterized by late production, since larger adult animals have higher maintenance energy requirements and also later finishing (Ramos et al., 2009).

A buffalo cow with large thoracic perimeter has long, separated and well-arched ribs, which provides an ample and deep thorax that facilitates respiratory functions (Lucena et al., 2015). These characteristics are good indicators for growth, adaptability and feed efficiency of animals (Oliveira \& Nogueira, 2006).

The largest thoracic perimeter and body length were found in Jafarabadi buffalo cows. Although Murrah buffalo cows had the shortest body length, their thoracic perimeter was statistically similar to that of the Mediterranean. The thoracic perimeter together with the body length form an anatomical area related to the limits of muscular tissue development and gain weight capacity (Koury Filho et al., 2010). Therefore, it is recommended to select buffalo cows within the herd considering their greater precocity and lower height in relation to thoracic perimeter and body length (Menezes et al., 2012; Rezende et al., 2014b).

Regarding the pelvic region, the sacropubic diameter was greater than the mean biiliac diameter, with significant breed differences. In all cases, the anatomical model of the pelvis was similar to an ellipse with vertical major axis, i.e., the birth canal had a lateral flattening. The main advantage of knowing these measures is to avoid fetal-pelvic incompatibility, i.e., large progeny and/or mature cow pelvis with measures smaller than the standard (Araújo et al., 2014).

Table 1. Body measures of buffalo cows (Bubalus bubalis) of the Jafarabadi ( $\mathrm{n}=78)$, Murrah ( $\mathrm{n}=221)$ e Mediterranean $(\mathrm{n}=113)$ breeds $^{(1)}$.

\begin{tabular}{|c|c|c|c|c|c|c|}
\hline \multirow{2}{*}{ Characteristic } & \multicolumn{2}{|c|}{ Jafarabadi } & \multicolumn{2}{|r|}{ Murrah } & \multicolumn{2}{|c|}{ Mediterranean } \\
\hline & Mean & Standard deviation & Mean & Standard deviation & Mean & Standard deviation \\
\hline Weight (kg) & $574.48 \mathrm{~A}$ & 83.93 & $527.50 \mathrm{~B}$ & 94.27 & $501.62 \mathrm{C}$ & 83.50 \\
\hline Thoracic perimeter & $219.17 \mathrm{~A}$ & 12.02 & 204.36B & 10.61 & $207.48 \mathrm{~B}$ & 12.47 \\
\hline Withers height & $141.73 \mathrm{~A}$ & 6.64 & $133.31 \mathrm{~B}$ & 5.96 & $134.63 \mathrm{~B}$ & 4.93 \\
\hline Rump height & 141.79A & 10.38 & $132.91 \mathrm{~B}$ & 5.55 & $134.20 \mathrm{~B}$ & 4.29 \\
\hline Body length & $161.21 \mathrm{~A}$ & 11.50 & $147.00 \mathrm{C}$ & 9.23 & $151.60 \mathrm{~B}$ & 8.31 \\
\hline External biiliac diameter & $65.15 \mathrm{~A}$ & 5.37 & $58.94 \mathrm{C}$ & 4.46 & $60.23 \mathrm{~B}$ & 3.98 \\
\hline External biischiatic diameter & $37.64 \mathrm{~A}$ & 3.76 & $31.89 \mathrm{~B}$ & 3.73 & $32.59 \mathrm{~B}$ & 3.29 \\
\hline Right ilioischiatic diameter & $46.97 \mathrm{~A}$ & 3.99 & $42.09 \mathrm{C}$ & 2.69 & $43.23 \mathrm{~B}$ & 2.43 \\
\hline Left ilioischiatic diameter & $47.16 \mathrm{~A}$ & 3.94 & $42.15 \mathrm{C}$ & 2.68 & $43.08 \mathrm{~B}$ & 2.74 \\
\hline Sacropubic diameter & $28.06 \mathrm{~A}$ & 2.34 & $25.90 \mathrm{C}$ & 2.49 & $26.77 \mathrm{~B}$ & 2.38 \\
\hline Internal mean biiliac diameter & $24.47 \mathrm{~A}$ & 1.96 & $21.86 \mathrm{~B}$ & 1.73 & $22.35 \mathrm{~B}$ & 1.85 \\
\hline
\end{tabular}

(1) Means followed by different letters, in the lines, differ by Tukey's test at 5\% probability. 
The withers-to-rump ratio and longitudinal pelvic zootechnical indexes were used to classify buffalo cows of the three breeds into similar profiles. Withersto-rump ratio of the breeds revealed a rectilinear body model, with balanced anterior and posterior heights. The longitudinal pelvic index indicated that the buffalo cows had equal capacity of muscular tissue development in body parts from which the most valuable cuts are extracted (Table 2).

The anamorphosis index of buffalo cows exceeded the 2.5 to 3.0 scale proposed by Marchiani Dubuc (1991) for dairy cattle (Table 2). Thus, the breeds' body model revealed a large thoracic perimeter in comparison to body height, with the highest results for the Jafarabadi breed.

In terms of pelvic index, the Jafarabadi breed had a proportionally larger than longer pelvis when compared with the other breeds. This index reveals the proportion that defines the pelvic canal of buffalo cows and consequently their calving ease (Contreras et al., 2011). All breeds had intermediate body index for milk and meat, according to the intervals established by Marchiani Dubuc (1991), i.e., 78 to 83 (for dairy breeds) and 64 to 70 (for beef breeds). This result confirms the double suitability of these three buffalo breeds in Brazil.

Regarding the lateral-body index, Rodríguez et al. (2001) evaluated Hereford and Holstein cow breeds and found lateral-body index equal to or lower than 78 for beef, and equal to or higher than 84 for dairy animals. Based on this index, the buffalo breeds evaluated in the present study were more suitable for milk than meat production. According to Contreras et al. (2011), the lower the value for this index, the higher the trend of the animal to a more compact biotype, which is a desirable model for animals intended for meat production.

The relative body index of all buffalo cows was greater than 1, which indicates better leg development, especially for the Jafarabadi. The Jafarabadi and Murrah buffalo cows had higher body capacity index 1 than the Mediterranean, whereas Jafarabadi had higher body capacity index 2 than the Murrah and Mediterranean. In both cases, Jafarabadi buffalo cows had higher results, which were due to their larger body size. Greater body capacity and minor leg development (compact biotype) are desirable characteristics for production animals. Thus, the Murrah breed had an interesting biotype for animal production, with minor leg development and good body capacity.

Jafarabadi buffalo cows had significantly higher transversal pelvic index, which indicates, as compared to Murrah and Mediterranean, a breed with greater capacity of muscular tissue development in body parts from which the most valuable cuts are extracted. The thoracic-perimeter-to-withers ratios showed that these buffalo cow breeds had moderate suitability for meat production, with the Jafarabadi and Mediterranean breeds having higher suitability.

The first canonical variable of the FDF explained $93.21 \%$ of the total variation among breeds (Table 3 ). The FDF coefficients showed higher values for the

Table 2. Zootechnical indexes of buffalo cows (Bubalus bubalis) of the Jafarabadi ( $\mathrm{n}=78$ ), Murrah ( $\mathrm{n}=221)$ e Mediterranean $(\mathrm{n}=113)$ breeds $^{(1)}$.

\begin{tabular}{|c|c|c|c|c|c|c|}
\hline \multirow[b]{2}{*}{ Characteristic } & \multicolumn{2}{|c|}{ Jafarabadi } & \multicolumn{2}{|c|}{ Murrah } & \multicolumn{2}{|c|}{ Mediterranean } \\
\hline & Mean & $\begin{array}{l}\text { Standard } \\
\text { deviation }\end{array}$ & Mean & $\begin{array}{l}\text { Standard } \\
\text { deviation }\end{array}$ & Mean & $\begin{array}{l}\text { Standard } \\
\text { deviation }\end{array}$ \\
\hline Anamorphosis index & $3.39 \mathrm{~A}$ & 0.28 & $3.13 \mathrm{~B}$ & 0.26 & $3.20 \mathrm{~B}$ & 0.32 \\
\hline Pelvic index & $80.46 \mathrm{~A}$ & 8.62 & $75.91 \mathrm{~B}$ & 8.96 & $75.49 \mathrm{~B}$ & 7.39 \\
\hline Withers-to-rump ratio & $1.00 \mathrm{~A}$ & 0.04 & $1.00 \mathrm{~A}$ & 0.02 & $1.00 \mathrm{~A}$ & 0.01 \\
\hline Body index & $73.00 \mathrm{~A}$ & 0.03 & $71.00 \mathrm{~B}$ & 0.04 & $73.00 \mathrm{~A}$ & 0.05 \\
\hline Lateral-body index & 88.14B & 4.40 & $90.91 \mathrm{~A}$ & 5.07 & 89.00B & 4.85 \\
\hline Relative body index & $1.13 \mathrm{~A}$ & 0.05 & $1.09 \mathrm{C}$ & 0.07 & $1.12 \mathrm{~B}$ & 0.06 \\
\hline Body capacity index 1 & $3.63 \mathrm{~A}$ & 0.53 & $3.33 \mathrm{~A}$ & 0.59 & 3.17B & 0.52 \\
\hline Body capacity index 2 & $2.62 \mathrm{~A}$ & 0.39 & $2.58 \mathrm{~B}$ & 0.47 & $2.43 \mathrm{~B}$ & 0.48 \\
\hline Transversal pelvic index & $45.94 \mathrm{~A}$ & 2.72 & $44.20 \mathrm{C}$ & 2.69 & $44.73 \mathrm{~B}$ & 2.44 \\
\hline Longitudinal pelvic index & $33.12 \mathrm{~A}$ & 2.00 & $31.58 \mathrm{~A}$ & 1.63 & $32.11 \mathrm{~A}$ & 1.53 \\
\hline Thoracic-perimeter-to-withers ratio & $1.54 \mathrm{~A}$ & 0.06 & $1.53 \mathrm{~B}$ & 0.06 & $1.54 \mathrm{~A}$ & 0.08 \\
\hline
\end{tabular}

(1) Means followed by different letters, in the lines, differ by Tukey's test at $5 \%$ probability. 
rear region, especially for the external biischiatic, left external ilioischiatic and pelvic indexes. When the FDF index was used as the dependent variable in the univariate analysis, significant differences were found between the means of Jafarabadi and other buffalo cows.

Despite the significant difference in the univariate analysis, measures of sacropubic index, internal average biiliac index, and body capacity index 2 were the least important variables to differentiate the breeds. The scatter biplot graph showed greater distances between the Jafarabadi buffaloes and the other breeds (Figure 1). This difference is explained by this breed's higher average measures of height, perimeter, body length; external biiliac, external biischiatic, left and right external ilioischiatic indexes; and pelvic index, lateral-body index, and transversal pelvic index (Figure 1).

Table 3. Fisher's linear discriminant function (FDF) ${ }^{(1)}$.

\begin{tabular}{lc}
\hline Characteristic & First canonical variable \\
\hline Weight & $-37.78^{*}$ \\
Thoracic perimeter & $-429.55^{*}$ \\
Withers height & $+2,036.14^{*}$ \\
Rump height & $+62.33^{*}$ \\
Body length & $+60.82^{*}$ \\
External biiliac index & $-1,710.66^{*}$ \\
External biischiatic index & $+4,754.65^{*}$ \\
Left ilioischiatic index & $-4,982.72^{*}$ \\
Right ilioischiatic index & $+11.50^{*}$ \\
Sacropubic index & $-5.15^{*}$ \\
Internal mean biiliac index & $+6.95^{*}$ \\
Anamorphosis index & $+241.83^{*}$ \\
Pelvic index & $-4,741.78^{*}$ \\
Withers-to-rump ratio & $+47.63^{*}$ \\
Body index & $+8.18^{*}$ \\
Lateral-body index & $+46.89^{*}$ \\
Relative body index & $-15.80^{*}$ \\
Body capacity index 1 & $+33.09^{*}$ \\
Body capacity index 2 & $+7.79^{*}$ \\
Transversal pelvic index & $+1,701.51^{*}$ \\
Longitudinal pelvic index & $+247.01^{*}$ \\
Thoracic-perimeter-to-withers ratio & $-38.72^{*}$ \\
\hline Breed & FDF \\
\hline Jafarabadi & $264,709.95 \pm 22,454.11 \mathrm{~A}$ \\
Murrah & $249,305.26 \pm 25,441.52 \mathrm{~B}$ \\
Mediterranean & $221.05 \pm 21,030.17 \mathrm{~B}$ \\
\hline
\end{tabular}

(1) Means followed by different letters, in the lines, differ by Tukey's test, at 5\% probability. *,**, and ***Significant at 10,5 and $1 \%$ probability, respectively.

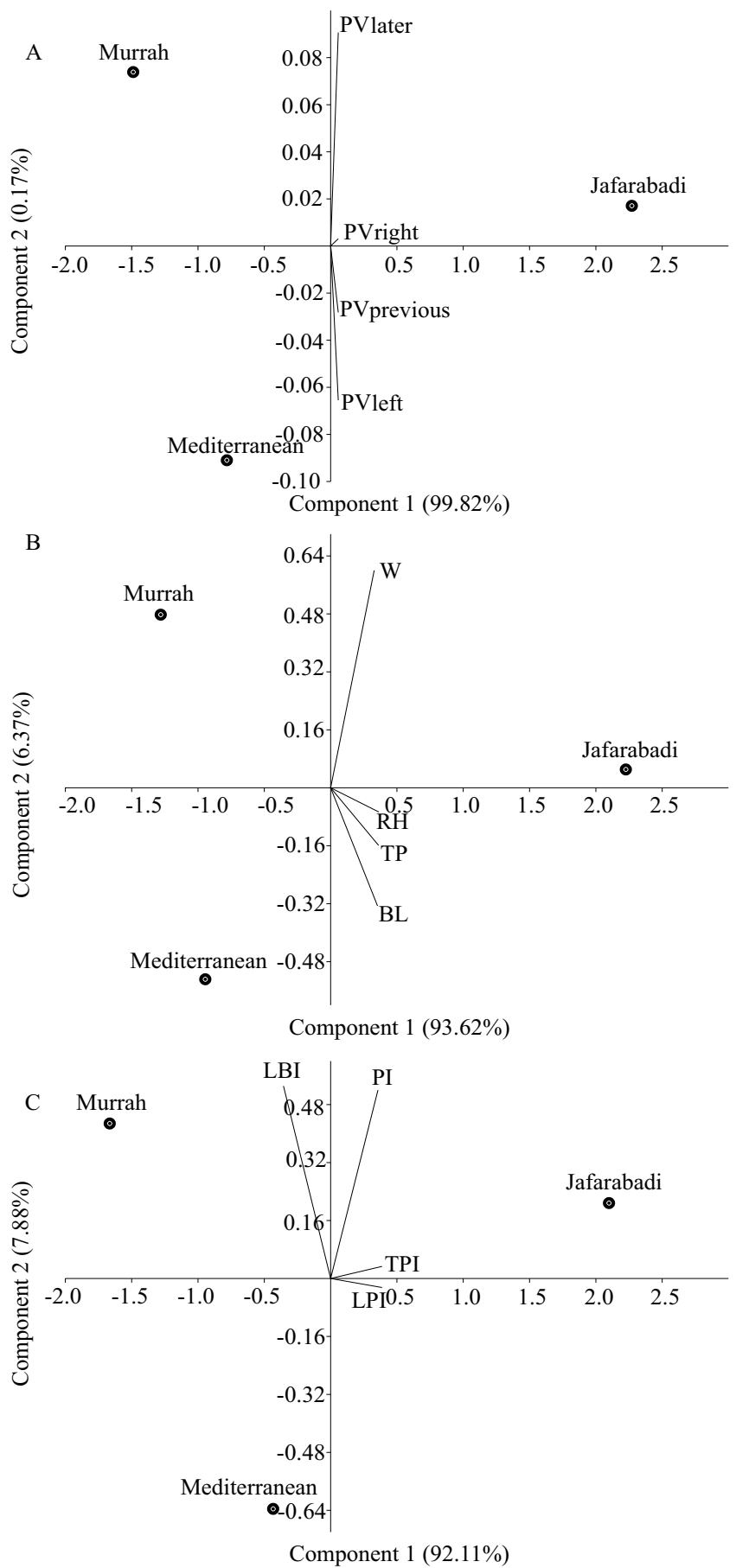

Figure 1. Scatter graphs for the Jafarabadi, Murrah and Mediterranean buffalo cow (Bubalus bubalis) breeds. Biplot with linear measurements (A); biplot with pelvic measurements (B); biplot with zootechnical indexes (C). PVlater, rear pelvic perimeter; PVprevious, fore pelvic perimeter; PVright, right pelvic perimeter; PVleft, left pelvic perimeter; $\mathrm{W}$, weight; $\mathrm{RH}$, rump height; TP, thoracic perimeter; BL, body length; LBI, lateral-body index; PI, pelvic index; TPI, transversal pelvic index; and LPI, longitudinal pelvic index. 
The analysis of generalized Mahalanobis distances between breed pairs confirmed the high dissimilarities between the Jafarabadi and Murrah $\left(\mathrm{D}^{2}=4.48\right)$ and Mediterranean $\left(\mathrm{D}^{2}=3.31\right)$ breeds, and low dissimilarities between the Murrah and Mediterranean $\left(\mathrm{D}^{2}=0.37\right)$ breeds. The introduction of Mediterranean genes in Murrah animals in Brazil may explain this low diversity between these two breeds (Marques et al., 2003). Albuquerque et al. (2006) used molecular markers and reported lower divergence rates between Mediterranean and Murrah (24.6\%) compared with Jafarabadi (29.9\%), thus reinforcing this hypothesis.

\section{Conclusions}

1. Buffalo cows of the Jafarabadi breed show large body size, with a rear portion wider than longer posterior region, whereas buffalo cows of the Murrah and Mediterranean breeds show similar biotypes, mainly differentiated in the pelvic region.

2. Jafarabadi, Murrah, and Mediterranean breeds have a similar capacity of muscular tissue development in body parts from which the most valuable cuts are extracted, and intermediate suitability for meat and milk production (double suitability).

\section{Acknowledgments}

To Dr. Alcides Ramos Amorim (in memoriam), for his invaluable contribution to Brazilian buffalo and animal production.

\section{References}

ALBUQUERQUE, M. do S.M.; EGITO, A.A. do; MARQUES, J.R.F.; CIAMPI, A.Y.; MARIANTE, A. da S.; CASTRO, S.T.R.; COSTA, M.R.; PAIVA, S.R.; SILVA, A.M. da; CONTEL, E.P.B. Variabilidade genética em búfalos estimada por marcadores RAPD. Pesquisa Agropecuária Brasileira, v.41, p.623-628, 2006. DOI: 10.1590/S0100-204X2006000400011.

ANDRADE, V.J. de; GARCIA, S.K. Padrões raciais e registro de bubalinos. Revista Brasileira de Reprodução Animal, v.29, p.39-45, 2005.

ARAÚJO, A.A. de O.; FARIAS, L.A.; BIAGIOTTI, D.; FERREIRA, G.J.B. de C. Pelvimetria de suínos das linhagens Agroceres e DanBred. Revista Brasileira de Ciência Veterinária, v.21, p.262-267, 2014. DOI: 10.4322/rbcv.2015.307.

BIANCHINI, E.; MCMANUS, C.; LUCCI, C.M.; FERNANDES, M.C.B.; PRESCOTT, E.; MARIANTE, A. da S.; EGITO, A.A. do. Características corporais associadas com a adaptação ao calor em bovinos naturalizados brasileiros. Pesquisa Agropecuária
Brasileira, v.41, p.1443-1448, 2006. DOI: 10.1590/S0100204X2006000900014.

CARNEIRO, P.L.S.; MALHADO, C.H.M.; SOUZA JUNIOR, A.A.O. de; SILVA, A.G.S. da; SANTOS, F.N. dos; SANTOS, P.F.; PAIVA, S.R. Desenvolvimento ponderal e diversidade fenotípica entre cruzamentos de ovinos Dorper com raças locais. Pesquisa Agropecuária Brasileira, v.42, p.991-998, 2007.

CERQUEIRA, J.O.L.; FEÁS, X.; IGLESIAS, A.; PACHECO, L.F.; ARAÚJO, J.P.P. Morphological traits in Portuguese Bordaleira de Entre Douro e Minho sheep: divergence of the breed. Animal Production Science, v.51, p.635-641, 2011. DOI: 10.1071/AN10147.

CONTRERAS, G.; CHIRINOS, Z.; ZAMBRANO, S.; MOLERO, E.; PAÉ, A. Caracterización morfológica e índices zoométricos de vacas Criollo Limonero de Venezuela. Revista de la Facultad de Agronomía, v.28, p.91-103, 2011.

DUBUC MARCHIANI, W. Zootecnia General. 3.ed. Caracas: Dumar, 1991. p.281-289.

HAMMER, Ø.; HARPER, D.A.T.; RYAN, P.D. PAST: paleontological statistics software package for education and data analysis. Palaeontologia Electronica, v.4, art. 4, 2001.

KOURY FILHO, W.; ALBUQUERQUE, L.G. de; FORNI, S.; SILVA, J.A.I. de V.; YOKOO, M.J.; ALENCAR, M.M. de. Estimativas de parâmetros genéticos para os escores visuais e suas associações com peso corporal em bovinos de corte. Revista Brasileira de Zootecnia, v.39, p.1015-1022, 2010. DOI: 10.1590/ S1516-35982010000500011.

LUCENA, J.E.C.; VIANNA, S.A. de B.; BERBARI NETO, F.; SALES FILHO, R.L.M.; DINIZ, W.J. da S. Estudo comparativo das proporções morfométricas entre garanhões e castrados da raça Campolina. Semina: Ciências Agrárias, v.36, p.353-366, 2015. DOI: 10.5433/1679-0359.2015v36n1p353.

MALHADO, C.H.M.; RAMOS, A. de A.; CARNEIRO, P.L.S.; SOUZA, J.C. de; PICCININ, A. Parâmetros e tendências da produção de leite em bubalinos da raça Murrah no Brasil. Revista Brasileira de Zootecnia, v.36, p.376-379, 2007. DOI: 10.1590/ S1516-35982007000200014.

MALHADO, C.H.M.; RAMOS, A.A.; CARNEIRO, P.L.S.; AZEVEDO, D.M.M.R.; AFFONSO, P.R.A. de M.; PEREIRA, D.G.; SOUZA, J.C. de. Estimativa de parâmetros genéticos para características reprodutivas e produtivas de búfalas mestiças no Brasil. Revista Brasileira de Saúde e Produção Animal, v.10, p.830-839, 2009

MALHADO, C.H.M.; RAMOS, A.A.; CARNEIRO, P.L.S.; AZEVEDO, D.M.M.R.; MARTINS FILHO, R.; SOUZA, J.C. Melhoramento e estrutura populacional em bubalinos da raça Mediterrâneo. Pesquisa Agropecuária Brasileira, v.43, p.215220, 2008.

MARQUES, J.R.F.; COSTA, M.R.; EGITO, A.A.; MARIANTE, A. da S.; ALBUQUERQUE, M.S.M. Conservation of genetic resources of the small populations of domestic animal of the Amazon Region in Brazil. Animal Genetic Resources Information, v.33, p.31-40, 2003. DOI: 10.1017/S1014233900001619. 
MELLO, F.A. de; SCHIMIDT, V. Caracterização biométrica de caprinos Anglo-Nubianos nascidos no Brasil, no período de 1993 a 2001. Archivos de Zootecnia, v.5, p.525-535, 2008.

MENESES, J.M.; VERGARA, D.M.; PORRAS, J.U.; QUINTERO, A.F.; ÁLVAREZ, J.C. Variabilidad morfoestructural de la hembra ovina de pelo criollo colombiana. Livestock Research for Rural Development, v.25, art. 83, 2013.

MENEZES, J.J.L. de; GONÇALVES, H.C.; CAÑIZARES, G.I.L.; RODRIGUES, L.; MEDEIROS, B.B.L. de; GOMES, H.F.B.; MARQUES, R.O.; EMERSON, M. de S. Ganho de peso e medidas biométricas de caprinos jovens em função do grupo racial, peso de abate e sexo. Veterinária e Zootecnia, v.19, p.574583, 2012.

MOITA NETO, J.M.; MOITA, G.C. Uma introdução à análise exploratória de dados multivariados. Química Nova, v.21, p.467469, 1998. DOI: 10.1590/S0100-40421998000400016.

OLIVEIRA, D. de J.C. de; NOGUEIRA, G. de P. Curvas de crescimento de bezerros da raça Girolando. Arquivos de Ciências Veterinárias e Zoologia da Unipar, v.9, p.3-8, 2006.

PERES-NETO, P.R. Introdução a análises morfométricas. Oecologia Brasiliensis, v.2, p.57-89, 1995. DOI: 10.4257/ oeco.1995.0201.03.

RAMOS, A.A.; MALHADO, C.H.M.; CARNEIRO, P.L.S.; AZEVEDO, D.M.M.R.; SOUZA, J.C. de. Critérios de seleção (GND e D160) para velocidade de crescimento em bubalinos de corte. Ciência Animal Brasileira, v.10, p.776-782, 2009.
REIS, S.F. dos; PESSÔA, L.M.; STRAUSS, R.E. Application of size-free canonical discriminant analysis to studies of geographic differentiation. Revista Brasileira de Genética, v.13, p.509-520, 1990.

REZENDE, M.P.G. de; LUZ, D.F.; RAMIRES, G.G.; OLIVEIRA, M.V.M. Índices zootécnicos de novilhas da raça Pantaneira. Veterinária e Zootecnia, v.21, p.550-555, 2014a.

REZENDE, M.P.G.; OLIVEIRA, N.M.; RAMIRES, G.G. Índices zootécnicos de ovinos cruzados criados em duas propriedades no Pantanal de Miranda, MS. Revista Agrarian, v.7, p.310-318, 2014b.

REZENDE, M.P.G.; SOUZA, J.C. de; MOTA, M.F.; OLIVEIRA, N.M.; JARDIM, R.J.D. Conformação corporal de equinos de diferentes grupos genéticos. Ciência Animal Brasileira, v.17, p.316-326, 2016. DOI: 10.1590/1089-6891v17i321194.

RODRÍGUEZ, M.; FERNÁNDEZ, G.; SILVEIRA, C.; DELGADO, J.V. Estudio étnico de los bovinos Criollos del Uruguay: I. análisis biométrico. Archivos de Zootecnia, v.50, p.113-118, 2001.

SINGH, D. The relative importance of characters affecting genetic divergence. Indian Journal of Genetics and Plant Breeding, v.41, p.237-245, 1981.

SOUZA, J.C. de; REZENDE, M.P.G. de; RAMIRES, G.G.; GONÇALVES, V.T.; SOUZA, C.F.; OLIVEIRA, N.M. de; RIBEIRO, R.V. Phenotypic traits of equines raised in the Pantanal of Mato Grosso do Sul. Semina: Ciências Agrárias, v.36, p.33413352, 2015. DOI: 10.5433/1679-0359.2015v36n5p3341.

$\overline{\text { Received on January 11, } 2016 \text { and accepted on September 30, } 2016}$ 